\title{
Szakmai követelmények a rendészeti felsőoktatásban
}

\section{BODA József ${ }^{1 \oplus}$}

\begin{abstract}
2019. augusztus 1-jétöl képviselem a Belügyminisztériumot (BM) a Nemzeti Közszolgálati Egyetem Tanácsadó Testületében (NKE TT). Ebben a beosztásban tolmácsolom a belügyi vezetés szakmai elvárásait az NKE és Rendészettudományi Karának (RTK) vezetői, tanárai és diákjai felé.

Ez a munka természetesen különböző formában és intenzitással folyt korábban is, a Rendörtiszti Föiskola müködése idején és az NKE RTK megalakulása után is.

Az NKE RTK megalakulása utáni első belügyminiszteri oktatási-képzési értekezletre és a miniszteri ajánlások megfogalmazására 2012. október 26-án, a BM-ben került sor, ahová az NKE Rektora, az RTK teljes oktatói kara meghivást kapott, és jelen voltak a BM, valamint a rendvédelmi szervek vezetői is. A feladatok és követelmények rövid és hosszú távon is meghatározták az RTK-n dolgozó munkatársak tevékenységét. Ezeket azután évente áttekintették és pontosították.
\end{abstract}

Kulcsszavak: Belügyminisztérium, Nemzeti Közszolgálati Egyetem, Rendészettudományi Kar, szakmai feladat, rendvédelmi szervek

\section{Bevezetés}

A magyar rendfenntartás kialakulásának kezdetét az Árpád-korra tesszük. Alapul véve A magyar rendvédelem története ${ }^{2}$ címú könyvet, a magyar rendvédelem fejlődésének első szakasza az Árpád-kortól a török kiűzéséig tartott; természetesen ebben az időszakban még nem beszélhetünk szervezetszerű rendvédelmi oktatásról. A rendfenntartás feladatait elsősorban a különböző típusú katonai alakulatok látták el. $\mathrm{Az}$ ország és a vármegyék tisztségviselőit általában a külföldi egyetemeken tanult nemesekből választották ki. A végrehajtói állomány csak igen hiányos felkészítésben részesült. A korabeli külföldi körülményekkel összehasonlítva a magyarországi állapotok megfeleltek az európai átlagnak.

Nem volt ez másképpen az abszolutizmustól a reformkorig terjedő második szakaszban sem, bár kétségtelen, hogy a rendvédelem a reformok hatására megerősödött.

\footnotetext{
Dr. habil. Boda József ny. nb. vezérőrnagy.

József Boda, PhD, habil, ret. National Security Major General.

E-mail: boda.jozsef@uni-nke.hu

2 Parádi József (szerk.): A magyar rendvédelem története. Budapest, Osiris, 1996.
} 
Kialakultak a rendvédelem polgári szerveinek alapjai, és megkezdődött elkülönülésük a hadseregtől.

A vezetők képzése továbbra is külföldi és magyar egyetemeken folyt.

A harmadik szakasz az 1848-49-es forradalommal kezdődött és a kiegyezéssel zárult.

Ebben az időszakban a rendvédelem újra katonai irányítás alá került. Az oktatás és képzés elsősorban az osztrák császári katonai iskolákban folyt.

A negyedik szakaszban, a kiegyezéstől az I. világháborúig terjedő időszakban megalakultak a magyar rendvédelem korszerű szervezetei, mint az állami és önkormányzati rendőrségek, a Magyar Királyi Csendőrség, a Magyar Királyi Pénzügyőrség és a vámhivatalok, a Budapest-fővárosi Rendőrség, a Képviselőházi Őrség, a büntetés-végrehajtás szervezete, továbbá megújulva múködött a tekintélyes múltú Magyar Királyi Koronaőrség, valamint a Magyar Királyi Nemesi Testőrség és új magyar testületként a Magyar Királyi Darabont Testőrség. Erre az időszakra tehető a rendvédelmi szakképzések beindítása is. A képzések nagy része itthoni iskolákban, kiképző objektumokban zajlott. A tiszti állomány egy része azonban továbbra is az osztrák katonai iskolákban tanult. ${ }^{3}$

A dualizmus idején már megjelentek a szakmai követelmények is a rendőrtisztekkel kapcsolatban. Például a Budapest-fővárosi Rendőrség tiszti karával szemben a közigazgatási tisztviselők képesítési követelményét állították, mivel a rendőrtiszteket is közigazgatási tisztviselőknek tekintették. A rendőrtiszti állás betöltéséhez többnyire a közigazgatásban eltöltött gyakorlati időt is előírtak. A rendőrkapitányi hivatás gyakorlásához a jogi végzettség (jogtudorság) és a huzamos, mintegy tízéves közigazgatási gyakorlat is hozzátartozott. A rendőri képzés bevezetése Török János (1843-1892) a budapesti államrendőrség főkapitányának nevéhez fűződik. ${ }^{4}$

A rendőrtiszti kar esetében a legfőbb gondot abban látták, hogy az államtudományi államvizsga nem készítette fel a leendő rendőrtiszteket hivatásuk teljesítésére. 1922-ben kezdődött meg a rendőri szakoktatás teljes körű kiépítése.

A két világháború közötti ötödik szakasz sem hozott lényeges változást a rendvédelmi szervezetek felépítésében, azonban létrehozták a Magyar Királyi Folyamőrséget és a Magyar Királyi Vámőrséget, amely 1931-től utódszervében, a Magyar Királyi Határőrségben, majd 1939-től a honvéd Határvadászok csapatnemben élt tovább.

A rendvédelmi szervezetek képzési és szolgálatellátási színvonala emelkedett. Ebben az időszakban már nemzetközi kapcsolatok alakultak ki a különböző rendvédelmi szervezetek között, és elvétve előfordult, hogy magyar tisztek tanultak külföldi rendvédelmi tanintézetekben (például csendőrtisztek Olaszországban, Ausztriában).

3 Boda József: A nemzetközi oktatás és képzés története a magyar rendvédelmi szervezeteknél. Rendvédelem-történeti Füzetek, 13. (2007), 16. 33.

4 Ismeretlen szerző: Történelmi visszapillantás. In Budaházi Árpád (szerk.): Jubileumi évkönyv. 35 éves a Rendőrtiszti Főiskola 1971-2006. Budapest, Rendőrtiszti Főiskola, 2006. 15. 
Külföldi tanulmányutakra és külföldi rendvédelmi küldöttségek látogatására is sor került. ${ }^{5}$

Számos beosztáshoz szakmai előírás volt a Ludovika Akadémiai végzettség, amely elsősorban a csendőrségnél, testőrségnél, koronaőrségnél és a képviselőházi őrségnél volt követelmény. ${ }^{6}$

A Magyar Királyi Rendőrségnél az alábbi szakmai képzési formák léteztek:

- Rendőrtisztviselői tiszti tanfolyam;

- Rendőrtisztviselőket továbbképző tanfolyam;

- Detektív tanfolyam;

- Detektívfelügyelői tanfolyam.

\section{Szakmai és politikai elvárások a rendőrtisztképzéssel kapcsolatban 1945 és 1990 között}

A II. világháborútól a rendszerváltásig tartó időszak lényeges változásokat hozott a rendvédelmi szervezetek feladataiban és a képzés területén is. A Magyar Királyi Csendőrséget, a Magyar Királyi Folyamőrséget és a Magyar Királyi Koronaőrséget megszüntették, illetve felszámolták. A Rendőrséget, Határőrséget, a Büntetés-végrehajtást és a Pénzügyőrséget átszervezték. Megalakult az Államvédelmi Hatóság. A szovjet mintára létrehozott rendvédelmi szervezetek fő feladata a szocialista állam érdekeinek védelme volt, és ennek megfelelően alakították ki az oktatással kapcsolatos szakmai és politikai követelményeket. A szinte teljesen lecserélt rendvédelmi személyi állomány képzésének megoldására létrehozták a Szaktanulmányi Felügyelőséget.

Hazánk szovjet megszállásával egy időben már Moszkvában és Debrecenben szovjet tanácsadók aktív közreműködésével létrehozták az Ideiglenes Nemzetgyűlést és az Ideiglenes Nemzeti Kormányt (INK). A Magyar Kommunista Párt és a szovjet vezetés a Belügyminisztérium hovatartozásának kérdésében kezdettől fogva határozott politikát folytatott. A rendőri vezetőket (Farkas Mihály, Sólyom László, Kádár János) is a Magyar Kommunista Párt delegálta. ${ }^{7}$

A rendőrtisztképzés fontosságát jelzi, hogy az INK már az 1690/1945. M. E. számú rendeletének 8. § (5) bekezdésében foglalkozott ezzel a témával. „A vármegyei főkapitányság keretében különleges rendőrségi alakulatok állíthatók fel, éspedig tanosztályok és tanfolyamok, amelyek keretén belül gondoskodni kell a rendőrség tagjainak demokratikus neveléséről is.” A II. világháború előtti tisztek közül körülbelül az állomány fele jelentkezett újbóli szolgálattételre, és az igazoló bizottságok ellenőrzése

\footnotetext{
Boda (2007): i. m. 34.

Parádi József: Rendvédelmünk képzési és képesítési rendszere 1867-1945. Rendvédelem-történeti Füzetek, 13. (2007), 16. 92.

7 Horváth Attila: A rendészeti szervek története Magyarországon a szovjet típusú diktatúra korában. Rendészet és Emberi Jogok, 1. (2011), 3. 4.
} 
után e létszám mintegy kétharmada állhatott munkába. Számukra párhetes tanfolyamot indítottak, valamint havi két-három napos szakmai összevonásokra került sor, amelyek levelező rendszerű felkészítést tettek lehetővé, és vizsgával zárultak. ${ }^{8}$

Az 1700/1945. M. E. számú rendelet 19. §-a az alábbiak szerint intézkedik: „A kinevezett személyek 1947. évi június hó 30-ig a belügyminiszter által külön rendeletben szabályozandó tanfolyamot köteles elvégezni és az elöírt vizsgát letenni."9

1946-ban kezdődött meg a háború utáni első tisztképző iskola, a Rendőr Akadémia megszervezése, Tömpe András rendőr vezérőrnagy (1913-1971) a Magyar Államrendőrség Vidéki Főkapitánysága Politikai Osztálya vezetőjének irányításával. Hosszú előkészítő munka eredményeként 1948. február 1-jén a Budapest XII. kerületében lévő Böszörményi úti volt csendőrlaktanyában nyitotta meg kapuit az Egyéves Tiszti Iskola, vagy más néven a Rendőr Akadémia. Az első végzett hallgatók ünnepélyes avatására 1949. március 15-én került sor. ${ }^{10} \mathrm{Az}$ Akadémia rövid életű volt, hiszen már 1949-ben átalakult tiszti tanfolyammá. A tanfolyamok időtartama 8-12 hónapos volt.

Dr. Katona Géza visszaemlékezése szerint 1950-től a középvezetők egy része a moszkvai Rendőrtiszti (Milicia) Főiskolán kapott eleinte egy, majd több éves képzést. Emellett felsőfokú tudományos képzésre (kandidátusi és doktori fokozatok megszerzése) államközi szerződés alapján biztosítottak lehetőséget a moszkvai egyetemi, akadémiai intézetekben.

Az Államvédelmi Hatóság (ÁVH 1948-1956) középvezetői számára az egyéves Dzerzsinszkij (Állambiztonsági) operatív iskolán (korábban 1950. november 1-jétől, Dzerzsinszkij Tiszti Tanosztály) 1951. október 1-jén indult meg a tisztképzés, a Széchenyi-hegyen (Budapest, XII. Farkasvölgyi út 12.) az Isteni Szeretet Leányai Kongregációja számára készült volt rendházban. Az épületben az államvédelmi tiszteket a legmagasabb fokon képző magyar oktatási intézményt rendezték be, amelyet a szovjet Összoroszországi Különleges Bizottság az Ellenforradalom és a Szabotázs elleni Harcra (Vé-Csé-Ká, „Cseka”) alapítójáról, Feliksz Edmundovics Dzerzsinszkijről (1877-1926) neveztek el. Vezetője a megalakuláskor Váradi József államvédelmi százados volt. A képzés időtartama, mint az elnevezéséből is kitűnik, először itt is egyéves volt.

A rendőrtisztek képzése 1951-1971 között különböző tanfolyamok keretei között zajlott. Volt Rendőr Akadémia (1948-1949) a már említett Böszörményi úti objektumban. Múködött ott Rendőrtisztképző Iskola, azon belül Rendőrtiszti Továbbképző Iskola (1950-1956, 360 fő, ebből 30 nő), Korvin Ottó Bűnügyi Szakiskola (1953-1954). Az Idegennyelvi Főiskola (1958) pedig a BM első és akkor egyetlen felsőfokú tanintézete csakis állambiztonsági tiszteket képezett az elhárítás igényeinek megfelelően intenzív nyelvi képzéssel.

\footnotetext{
8 Kozáry Andrea: Rendőrtisztképző iskolák Magyarországon 1945 után. In Molnár Katalin (szerk.): Társadalomtudományi kutatások-Rendvédelmi képzés. Budapest, Rendőrtiszti Főiskola Társadalomtudományi Tanszék, 2001. 15. Az 1700/1945. M. E. számú rendelet 19. §.

10 Kozáry (2001): i. m. 19.
} 
1959-ben azután már mint kétéves BM Rendőrtiszti Akadémia (RA) müködött. A képzés nappali tagozaton két év, levelező tagozaton három év volt. Az RA mellett a Magyar Néphadsereg Egyesített Tiszti Iskoláján (MN ETI) 1960-tól létrehozták a BM Akadémia Határőr és Karhatalmi Tagozatát. A Tagozat végezte a határőr, karhatalmi és 1963-tól a munkásőr tisztek képzését. Az ETI 1967-ben beolvadt az MN Kossuth Lajos Katonai Főiskolába. ${ }^{11}$

Az 1960-as évek közepétől háromévenként körülbelül 15 fős csoportok képzésére került sor a moszkvai Rendőrtiszti Főiskolán kétéves időtartamban. Ide már rendőri, bűnügyi technikai gyakorlattal rendelkező fiatal tiszteket vezényeltek. A képzés az 1980-as évek végéig folyt, és nagyjából 100 fő képzésére került sor.

A Rendőrtiszti Főiskolát (RTF 1971-2012) az Elnöki Tanács 1970. évi 39. számú törvényerejű rendeletével alapították meg, és 1971. szeptember 1-jén kezdte meg múködését, a korábbi Dzerzsinszkij (Állambiztonsági) operatív iskola helyszínén (Budapest, XII. Farkasvölgyi út 12.). Alapvető feladatait, működésének elveit a 4/1971 (X. 19.) BM rendelet és a 010/1971. BM. számú parancs határozták meg.

A képzés nappali tagozaton három, levelező tagozaton (1975-től) négy éven keresztül folyt. Az RTF felügyeletét a belügyminiszter látta el. A rendelet feladatul szabta az RTF számára a belügyminiszter által meghatározott tiszti, köztisztviselői és közalkalmazotti munkakörök betöltésére alkalmas, magas képzettségű rendőrtisztek felkészítését, valamint az Igazságügyi Minisztérium büntetés-végrehajtási tiszti állományának utánpótlás-biztosítását. A Főiskola egykarú intézményként alakult meg, és állambiztonsági, bűnügyi, büntetés-végrehajtási, igazgatásrendészeti, valamint közbiztonsági szakokon indult el a képzés. 1987-től vámnyomozói szakkal bővült az oktatás. Az állambiztonsági (politikai nyomozó) szak 1990-ben, a katonai elhárító szak és az idegennyelvi pedig már 1973-ban megszűnt.

Az 1980-as évek elején a volgográdi Rendőrtiszti Főiskolán beindult a kétéves bűnügyi technikai, szakértői képzés, ahol két-három csoportot képeztek ki. Ugyanitt négy-hat hónapos továbbképző tanfolyamok is zajlottak magyar szakemberek számára.

1980 és 1990 között a berlini Humboldt Egyetem Kriminalisztikai Fakultásán tanultak magyar rendőrtisztek. Itt körülbelül nyolc-tíz fő végzett.

A Rendőrtiszti Főiskolán már megalakulása - 1971 - óta folyt valamilyen formában nemzetközi tartalmú oktatás és képzés. Kezdetben az állambiztonság területét illetően - orosz vendégtanárok bevonásával - zajlott a képzés, 1973-tól pedig a Főiskola szaktanárai és az állambiztonsági hallgatók egy része tanult a Szovjetunióban.

1978-ban fogadta az RTF az első külföldi hallgatókat Vietnámból. A vietnámiak mellett képeztek mozambiki, lengyel, nicaraguai és jemeni diákokat is a rendszerváltásig, mintegy 250 fős létszámmal.

11 Ismeretlen szerző (2006): i. m. 18-20. 
A tanári állomány egy szúkebb csoportja részére lehetőséget biztosítottak a külföldi továbbképzésre is. Ezek eleinte a Szovjetunióban és a Német Demokratikus Köztársaságban zajlottak. 1987-ben az RTF Idegennyelvi Tanszékének tanárai (három fő) a British Council támogatásával Brightonban vett rész nyelvi továbbképzésen.

Az 1980-as évekig teljes mértékben „zárt beiskolázású” volt az intézmény. Elsősorban a rendőrség hivatásos tiszthelyettesi állományának biztosított továbbtanulási lehetőséget. A beiskolázás, az akkori káderpolitikai elképzelések, az állományilletékes parancsnok kezdeményezésére a Belügyminisztériumon keresztül realizálódott. Az 1980-as évek közepén fogalmazódott meg a szándék és követte felvételi eljárásokban is a magyar felsőoktatáshoz igazodás gyakorlata. Az 1980-as évek végétől kezdődően a Rendőrtiszti Főiskola felvételi eljárásának rendje, hasonlóan a magyar felsőoktatás valamennyi intézményéhez, kormányrendeletben előírtaknak megfelelően történt.

Az eljárás általános rendjétől eltérő követelményeket - a felsőoktatási törvény felhatalmazása alapján - az intézményt fenntartó miniszter határozta meg.

\section{A szakmai követelmények változása a rendszerváltoztatás után}

A rendszerváltoztatás utáni első szabadon választott magyar kormány 1990. május 23-án lépett hivatalba. Ez természetesen magával vonta a fegyveres és rendvédelmi szervek átalakítását, beleértve az általuk végzett feladatok, és a számukra meghatározott követelmények megváltoztatását is. A rendszerváltoztatás hatására az oktatás átalakult. Megszűnt az állambiztonsági szak és a pártpolitikai befolyás. A rendvédelmi szervek igényeinek megfelelően új szakok alakultak: 1991-től vámigazgatási, 1992-től határrendészeti, 2000-től gazdaságvédelmi, 2003-tól katasztrófavédelmi szak.

„Látszólag azonban a Belügyminiszter közvetlen felügyelete alatt álló RTF-ről mintha (legalábbis e felső, miniszteriális szinten) »megfeledkeztek « volna. Az elkövetkezendő évek során, egészen 1996-ig, a rendvédelmi szakemberek felsőfokú alapképzése nem szerepelt miniszteri értekezlet önálló napirendjén. A civilesítés az RTF-et is elérte, melyet alapításától fogva a BM ún. zárt felsőoktatási intézményként, belső beiskolázási rendben múködtetett. A rendszerváltozással a főiskola a közrendvédelmi és BV szakok kivételével megnyitotta kapuit a polgári életből jelentkező fiatalok számára is. Egyúttal pedig 1991-ben sor került a Vám- és Pénzügyőr Tanszék ${ }^{12}$ létrehozására, továbbá 1992-ben megindult a képzés a határrendészeti szakon is, az újonnan alapított Határrendészeti Tanszék gondozásában. A fejlesztési munkálatok első szakasza az 1990-1994 közötti időszakra tehető. Ennek a periódusnak a következő sajátosságai érdemelnek említést:

12 Megrendelői igényre 1987-ben még csak levelező tagozaton, de megindult a vámnyomozó képzés. A tanszék portfóliója az 1991-es megalakulását követően vámigazgatási szakkal vált teljessé, mind a nappali mind a levelező tagozatos képzésben. 
Az ORFK 1993-ban elkészítette az Egységes - háromszintű - Rendőrszakképzés Koncepcióját (1994-1996). Megszűnt a korábbi minisztériumi szintû oktatásfelügyelet. Az Országos Rendőr-főkapitányságnak a Belügyminisztérium szervezetéből történt kiválásával tovább nőtt a távolság a rendvédelmi felsőfokú szakképzés gerincét alkotó rendőrtisztté válás és a végrehajtó szolgálatok munkája között. Eltekintve egy részvizsgálattól (amelyet a Team Consult végzett), elmaradt a tanintézet helyzetét pontosan felmérő állapotanalízis, noha ez egy megalapozott tervező munkához feltétlenül szükséges lett volna.

Az alapvetô stratégiai célkitüzés a hazai felsőoktatás általános-, illetőleg a Büntetés-végrehajtás, a Határőrség, a Rendőrség, a Vám- és Pénzügyőrség speciális elvárásait maradéktalanul teljesítő és a nemzetközi normákhoz is illeszkedő, azzal egyenértékűsíthető oklevelet kibocsátó képzés folytatása, amelyben ötvöződnek a civil felsőoktatás és a tisztképzés értékei, továbbá, amelynek két összetevője, az oktatás és a személyiségformálás/nevelés szoros egységet képez.

A BM 2003-ban elrendelte az RTF átfogó ellenőrzését. A 2005-ös visszatérő ellenőrzés megállapította az átfogó ellenőrzés alapján készített intézkedési tervünkben foglaltak időarányos végrehajtását.

2004. május 1-jén hazánk az Európai Unió teljes jogú tagjává vált, de az RTF egyetemmé válása szempontjából is több kiemelkedő fontosságú esemény történt. Már ebben a hónapban »felpörögtek« az események. Az RTF Tanácsa május 12-én elfogadta A Bolognai Folyamat adaptációja az RTF-n címú előterjesztést. Május 14-én pedig felterjesztettük a MAB-nak - bírva a BM és a megrendelő szervek támogatását - a felsőoktatási alapszakokhoz szükséges szakalapítási beadványt. A MAB a 2004. szeptember 29-én hozott határozataival támogatta a bűnügyi igazgatási, illetve a rendészeti igazgatási alapszak képzési és kimeneti követelményeinek (a szakalapításoknak) az engedélyezését."13

Az RTF életében a legnagyobb változás a Nemzeti Közszolgálati Egyetem 2011-es alapítása és az NKE Rendészettudományi Karának 2012. január 1-jei létrejötte volt.

\section{A szakmai követelmények változása az egyetemi karrá válás után}

Az NKE-vel kapcsolatos döntéseket az Egyetem alapítása után a Fenntartói Testület (FT) hozta, és a követelményeket is ez a testület határozta meg. Az NKE Alapító Okirata szerint az irányítói és fenntartó jogokat a FT gyakorolta, amelynek tagjait a Belügyminisztérium, az Igazságügyi Minisztérium, a Honvédelmi Minisztérium és a Miniszterelnökség gyakorolták. A FT döntései csak egyhangú határozat esetén voltak végrehajthatók! ${ }^{14}$

\footnotetext{
Blaskó Béla: A rendészeti felsőoktatás fejlődése a rendszerváltástól az egyetemi karrá válásig. In Christián László - Lippai Zsolt - Németh Zsolt: A rendszerváltás hatása a rendészetre. (megjelenés alatt) 3.

14 A Nemzeti Közszolgálati Egyetem Alapító Okirata, I. 5.
} 
Jelenleg az egyetem irányítását a fenntartó minisztérium végzi. A minisztérium munkáját egy Tanácsadó Testület segíti.

\section{„II/A. fejezet}

A Tanácsadó Testület

9/B. § (1) Az Egyetem mellett a Fenntartó vezetésével, az igazságügyért felelős miniszter, a honvédelemért felelős miniszter, az oktatásért felelős miniszter, az innovációért és technológiáért felelős miniszter, a külpolitikáért felelős miniszter, valamint a rendészetért felelős miniszter részvételével a Fenntartó egyes döntéseinek megalapozását és szakmai támogatását elősegítő Tanácsadó Testület múködik.

(2) Az (1) bekezdésben felsorolt miniszterek képviseletét a Tanácsadó Testületben az általuk megbízott más személy is elláthatja.

9/C. § A Tanácsadó Testület feladatai különösen

a) az Egyetem költségvetésének, képzési és kutatási programjának, a szervezeti és múködési szabályzatának, a minőségfejlesztési programjának, az intézményfejlesztési tervének véleményezése, valamint

b) az Egyetemre felvehető hallgatói létszám szakonkénti megosztására vonatkozó javaslattétel.

9/D. § (1) A Tanácsadó Testület tagjainak a Tanácsadó Testületben végzett tevékenysége oktatási tevékenységnek minősül."15

A TT tagjai szakmai segítséget nyújtanak a fenntartó minisztérium és az NKE vezetése számára.

A belügyminisztérium képviselője elsősorban a BM irányítása alá tartozó rendvédelmi szervek és a vízügyi ágazat vonatkozásában végez szakmai tanácsadást.

A Rendészettudományi Kar tekintetében ez a szakmai segítségnyújtás kiterjed a rendvédelmi szervek, így különösen a Rendőrség, a Büntetés-végrehajtási Szervezet, a Nemzeti Adó- és Vámhivatal, az Országos Katasztrófavédelmi Főigazgatóság, továbbá az Országos Idegenrendészeti Hivatal, a nemzetbiztonsági szolgálatok, és a magánbiztonsági szféra számára a tiszti, közalkalmazotti, köztisztviselői és kormánytisztviselői, magánbiztonsági munkakörök betöltésére hivatott, felsőfokú szakképzettségű szakemberekre vonatkozólag.

A Kar jelenlegi helyzetét:

- a nemzeti felsőoktatásról szóló 2011. évi CCIV. törvény (Nftv.);

- a Nemzeti Közszolgálati Egyetem létesítéséről szóló 2011. évi XXXVI. törvény;

- a Nemzeti Közszolgálati Egyetemről, a közigazgatási, rendészeti és katonai felsőoktatásról szóló 2011. évi. CXXXII. törvény;

- a rendvédelmi feladatokat ellátó szervek hivatásos állományának szolgálati jogviszonyáról szóló 2015. évi XLII. törvény (Hszt.);

\footnotetext{
2011. évi CXXXII. törvény a Nemzeti Közszolgálati Egyetemről, valamint a közigazgatási, rendészeti és katonai felsőoktatásról.
} 
- az Egyetem Intézményfejlesztési Terve és

- a rendvédelmi szervek vezetőinek elvárása határozzák meg.

Szakmai és tudományos téren is nagy előrelépés volt, hogy az Oktatási Hivatal 2015. december 11-én akkreditálta a Rendészettudományi Doktori Iskolát (RDI), ami mérföldkövet jelent nemcsak a Kar, hanem a rendészettudományt múvelő tudósok és doktoranduszok számára is. ${ }^{16}$

Az RTK szervezetében jelenleg 20 tanszék és a Katasztrófavédelmi Intézet, amelyen belül három tanszék (Iparbiztonsági Tanszék, Katasztrófavédelmi Müveleti Tanszék, Tüzvédelmi és Mentésirányítási tanszék), valamint egy Idegennyelvi és Szaknyelvi Lektorátus működik. Az intézeti szervezésben együttműködő tanszékek még a Polgári Nemzetbiztonsági Tanszék és a Terrorelhárítási Tanszék. A sajátos feladatot ellátó szervezeti egységek közül kiemelkedik a Rendészeti Kiképzési és Nevelési Intézet, ehhez csatlakozik a Diószeghy utcai Kollégium, az Intézkedéstaktikai és Informatikai Csoport, valamint a Rendvédelmi Tagozat.

Fontos feladat a BM számára a tehetséggondozás, ezért a szakmai támogatás kiterjed a karon működő Tudományos Diákköri Tanács, a Kari Hallgatói Önkormányzat működésére, a nappali munkarendben tanuló hallgatók részére létrehozott Szent György Szakkollégiumra, a Katasztrófavédelmi Szakkollégiumra és a Rendészetelméleti Kutatóműhelyre is.

A nemzetközi kapcsolatok terén szakmai segítséget nyújt a BM a rendészeti felsőoktatás nemzetközi szereplőivel (Európai Rendőrtiszti Főiskolák Szövetsége - AEPC, Európai Rendőr Akadémia - CEPOL, a Német Rendőrség Egyeteme - GPU stb.) kiépített kapcsolatok fenntartásához és fejlesztéséhez.

A szakmai követelményekhez szorosan hozzátartozik a hallgatók fizikai felkészítése, ezért a BM és a rendvédelmi szervek támogatják az NKE Sportegyesület szakosztályainak működését. A Sportegyesület közhasznú tevékenységével lehetőséget biztosít a hivatásos szolgálathoz kapcsolódó szolgálati sportokhoz, a szabadidő hasznos, kulturált eltöltéséhez, az egészségmegőrzéshez, a betegségmegelőzéshez, a testi, szellemi képességfejlesztéshez, a tömegsporthoz és meghatározott körben a versenysporthoz, és elkötelezett a környezetvédelem céljainak megvalósításában.

Fontosnak tartja a belügyi vezetés a Belügyi Tudományos Tanáccsal, a Rendőrség Tudományos Tanácsával, a rendvédelmi szervek tudományos szervezeteivel, a rendészeti kutatással és tudományos munkával foglalkozó hazai (Magyar Rendészettudományi Társaság - MRTT, Magyar Kriminológiai Társaság - MKT, Országos Polgárőr Szövetség - OPSZ, Szemere Bertalan Magyar Rendvédelem-történeti Tudományos Társaság - SZBMRTT stb.) és nemzetközi civil szervezetekkel, oktatási intézményekkel (Rendőrfőnökök Nemzetközi Szövetsége, International Association of Chiefs of Police - IACP, Rendőri Jövőkutatók Nemzetközi Szövetsége, Police Futurists

16 Oktatási Hivatal FF/396-12/2015. számú határozata (2015. december 11.). 
International - PFI, Marymount Egyetem stb.) történő szoros kapcsolattartást és közös munkát.

\section{A hallgatók szakmai, parancsnoki/vezetői felkészítésének és hivatásra nevelésének feladatai, a belügyminiszteri ajánlásokban és a rektori feladatszabásban foglaltak megvalósítása}

A Kar tevékenységének középpontjában a hallgatókkal való foglalkozásnak kell állnia! Ennek a munkának a Kar életében már a rendvédelmi pályára irányítás szakaszában szükséges megjelennie. Az RTK-ra a többszörös túljelentkezés miatt válogatott és jól felkészült hallgatói állomány kerül be.

A Kar hallgatói részére a legkorszerübb rendészeti, szakmai és információtechnológiai ismeretek átadása a cél. Ennek a célnak a technikai kivitelezése a Kar 2017-es költözésével teljes mértékben megvalósult.

A cél elérésének elengedhetetlen feltétele ezen kívül az idegen nyelvek ismerete, alkalmazása és a nemzetközi tapasztalatok megszerzése a tanulmányok során.

Fontos feladatként jelentkezik az alapképzés és a nyári szakmai gyakorlatok hatékonyabbá tétele, a rendvédelmi szervekkel együttmúködve. A szakmai követelményeknek megfelelően a hallgatókat a rendvédelmi szervek állományából kijelölt és az RTK által felkészített mentorok tanítják, irányítják és vezetik a szakmai gyakorlatok idején.

A Kar rendvédelmi területen tanuló hallgatóinak parancsnoki, vezetői feladatokra történő hatékonyabb felkészítése, a gyakorló parancsnoki (szakasz-, rajparancsnok-) rendszer eredményesebb múködtetése továbbra is szakmai feladatként jelentkezik. A cél továbbra is a felsőbb éves hallgatók aktívabb bevonása az alsóbb évesek irányításába. A hallgatók gyakorlati ismereteinek fejlesztése érdekében, a felsőbb évfolyamos hallgatókat bevonják rész- (segéd) foglakozásvezetőként az alsóbb évfolyamokon oktatott szakmai tárgyak gyakorlati oktatásába. El kell érni, hogy a negyedik év végére készségszinten ismerjék a parancsnoki, vezetői munka alapjait. ${ }^{17}$

A frissen avatott büntetés-végrehajtási, rendőr- és pénzügyőrtiszteknek alkalmasnak kell lenniük alosztályvezetői, alparancsnoki beosztások betöltésére és szolgálatszervezési feladatok ellátására.

A hivatástudatra, az etikus szakmai és vezetői munkára történő felkészítés részét kell, hogy képezze a hallgatók minden napi életének. Ehhez részletesen ismerniük kell a fegyveres és rendvédelmi szervek, az Egyetem és elődszervezetei hagyományait, történetét. Be kell vonni a nappali munkarendben tanuló hallgatókat a rendvédelmi szervek hagyományőrző tevékenységébe.

Kovács Gábor: A Nemzeti Közszolgálati Egyetem alapképzésben végzett rendőrtisztekkel szemben támasztott követelmények változásai. Pécsi Határör Tudományos Közlemények, 17. (2016), 259-264. 
Szükséges, hogy a hallgatók megismerjék a rendvédelmi szerveknél zajló időszerű szervezeti és a hivatásos léttel kapcsolatos változásokat, mint például a rendészeti életpályamodell, illetve a belügyi teljesítményértékelési rendszer működése.

A szakmai felkészítés erősítése érdekében rendszeresen - évfolyamonként, szakaszonként - rendészeti foglalkozás megszervezése szükséges a hallgatók (tisztjelöltek) számára (többek között rendőri akciók, esettanulmányok feldolgozása, szakmai látogatások, ügyeleti és tevékenységirányítási feladatok, alaki foglalkozások, fegyverkezelés, lövészet, hallgatói tájékoztatók stb.), a Rendészeti Kiképzési és Nevelési Intézet terve alapján.

Fontos feladat a hallgatók mind szélesebb körének bevonása az Egyetemen és a Karon múködő tudományos, sport- és szakmai műhelyekbe. Leendő vezetőként meg kell, hogy ismerjék a civil szervezetekkel való együttműködésben rejlő lehetőségeket.

A vezetői kiválasztás rendszerét és a vezetőképzés tartalmát a miniszteri elvárásoknak megfelelően összehangolták az RTK és a BM Rendészeti Vezetőkiválasztási, Vezetőképzési és Továbbképzési Főosztály között.

A rendvédelmi feladatokat ellátó szervek hivatásos állományának szolgálati jogviszonyáról szóló 2015. évi XLII. törvény (Hszt.) 343. § (2) bekezdése alapján 2016. július 1-jén hatályba léptek a Hszt. tisztjelölti jogállásra vonatkozó rendelkezései.

A Hszt. 285. § (4) bekezdése alapján tisztjelölt a beiratkozást követő hat hónapig rendészeti alapfelkészitésen vesz részt. A rendészeti alapfelkészités befejezése után a tisztjelölt a rendvédelmi szerv hivatásos tagja számára előírt esküt tesz.

A rendvédelmi tisztjelölt a vele szerződést kötő rendvédelmi szerv rendelkezési állományába tartozik, de a szolgálatteljesítés helye a Nemzeti Közszolgálati Egyetem Rendészettudományi Kar Rendvédelmi Tagozata (Rendvédelmi Tagozat - RT). A Tagozat igénybevételét a Nemzeti Közszolgálati Egyetem rektoránál kell kezdeményezni. A Rektor - a különleges jogrendi helyzetekben való alkalmazás és a rendészetért felelős miniszter által elrendelt feladatok végrehajtása kivételével - a Rendészettudományi Kar dékánja szakmai véleményének figyelembevételével dönt az engedélyezésről. Erre az igénybevételre a 2020-as évben a Covid-járvány miatt sor is került.

A megnövekedett szakmai követelmények és a folyamatosan növekvő tudásanyag elsajátítása végett bevezették a négyéves alapképzést a 2017/18-as tanévben.

A négyéves képzésre történő áttérést az Országos Rendőr Főkapitányság (ORFK), a Nemzeti Adó- és Vámhivatal (NAV), a Büntetés-végrehajtás Országos Parancsnokság (BVOP), illetve a Bevándorlási és Menekültügyi Hivatal (BMH), indokoltnak látták, illetve az ebből származó költségeket vállalták.

Az új egyéves mesterképzést először 2021 szeptemberében lesz szükséges indítani. Ugyanakkor továbbra is fenn kell tartani a kétéves mesterképzést is, az eddig hároméves BA-képzést végzettek számára.

A Karon öt mesterszakon folyik képzés: a rendészeti vezető mesterképzésen, a kriminalisztika mesterképzési szakon, a katasztrófavédelem mesterképzési szakon, a polgári nemzetbiztonsági mesterképzési szakon és a biztonsági szervező mesterképzési 
szakon. Az egyetem megbízásából szakfelelősök gondozzák az ott folyó képzéseket, szorosan együttmúködve a rendvédelmi szervek szakszolgálataival.

Kiemelt feladatként jelentkezik még a rendészeti vezető mesterképzésben a nappali munkarendű képzés és tűzvédelmi mérnök alapképzési szak beindítása.

\section{Összegzés}

A rendészeti felsőoktatásnak a jövő biztonsági kihívásaira, mint a kiberbiztonság és a mesterséges intelligencia, is képesnek kell lennie felkészíteni az itt tanuló fiatalokat.

A rendészeti felsőoktatás sikerességének fontos feltétele a BM-mel és a rendvédelmi szervekkel történő aktív kapcsolattartás és a folyamatos párbeszéd, vezetői és oktató szinten egyaránt.

A rendészeti képzésnek a hallgatói állományra szükséges koncentrálnia. Az a feladat, hogy a rendvédelmi szervek számára olyan korszerú szakmai tudással, erkölcsi értékkel és emberi tulajdonságokkal rendelkező hallgatókat biztosítson, akik mind itthon, mind pedig külföldön megállják a helyüket.

Fontos a szoros kapcsolat fenntartása az egyetem más karaival és intézeteivel, valamint a Karral együttmúködő külföldi és nemzetközi rendvédelmi szervekkel, szakmai és civil szervezetekkel.

\section{FELHASZNÁLT IRODALOM}

Blaskó Béla: A rendészeti felsőoktatás fejlődése a rendszerváltástól az egyetemi karrá válásig. In Christián László - Lippai Zsolt - Németh Zsolt: A rendszerváltás hatása a rendészetre. 3. (megjelenés alatt)

Boda József: A nemzetközi oktatás és képzés története a magyar rendvédelmi szervezeteknél. Rendvédelem-történeti Füzetek, 13. (2007), 16. 33-45. Online: http://epa.oszk. hu/02100/02176/00002/pdf/RTF_16_033-045.pdf

Horváth Attila: A rendészeti szervek története Magyarországon a szovjet típusú diktatúra korában. Rendészet és Emberi Jogok, 1. (2011), 3. 3-30.

Ismeretlen szerző: Történelmi visszapillantás. In Budaházi Árpád (szerk.): Jubileumi évkönyv. 35 éves a Rendőrtiszti Főiskola 1971-2009. Budapest, Rendőrtiszti Főiskola, 2006.

Kovács Gábor: A Nemzeti Közszolgálati Egyetem alapképzésben végzett rendőrtisztekkel szemben támasztott követelmények változásai. Pécsi Határör Tudományos Közlemények, 17. (2016). 259-264.

Kozáry Andrea: Rendőrtisztképző iskolák Magyarországon 1945 után. In Molnár Katalin (szerk.): Társadalomtudományi kutatások - Rendvédelmi képzés. Budapest, Rendőrtiszti Főiskola Társadalomtudományi Tanszék, 2001.

A Nemzeti Közszolgálati Egyetem Alapító Okirata

Parádi József (szerk.): A magyar rendvédelem története. Budapest, Osiris, 1996.

Parádi József: Rendvédelmünk képzési és képesítési rendszere 1867-1945. Rendvédelem-történeti Füzetek, 13. (2007), 16. 90-93. Online: http://epa.oszk.hu/02100/02176/00002/pdf/ RTF_16_090-093.pdf 


\section{Jogi források}

1700/1945. M. E. számú rendelet

2011. évi CXXXII. törvény a Nemzeti Közszolgálati Egyetemről, valamint a közigazgatási, rendészeti és katonai felsőoktatásról

Oktatási Hivatal, FF/396-12/2015. számú határozata (2015. december 11.)

\section{ABSTRACT}

Professional Requirements in Law Enforcement Higher Education

József BODA

From 1 August 2019, I represent the Ministry of the Interior (BM) on the Advisory Board of the University of Public Service (NKE TT). In this position, I convey the professional expectations of the Internal Affairs Leadership to the heads, teachers and students of the NKE and its Faculty of Law Enforcement (RTK).

This work has, of course, been carried out in different forms and with different intensity in the past, during the operation of the Police College and after the formation of the NKE RTK.

The first education training meeting of the Minister of the Interior after the establishment of the NKE RTK and ministerial recommendations were drafted on 26 October 2012 in the BM, to which the Rector of the NKE, the entire faculty of the RTK was invited, and the heads of the BM and law enforcement agencies were present.

The tasks and requirements defined the activities of its staff at the RTK in the short and long term. These were then reviewed and clarified annually.

Keywords: Ministry of the Interior, University of Public Service, Faculty of Law Enforcement, professional task, law enforcement agencies 